【結果・考察】シミュレーションで得られた三次元画像により, 水中 に拈ける線源からの放出光子の挙動が視覚的に確認できた．また水 中におけるエネルギー損失の分布図も得られ，今後は現行の線量計 算ソフトとの線量分布の比較が課題である.

316 婦人科領域の腔内照射における重要蔵器線量低隇の工夫 滋賀医科大学 綱 裕人, 本多恵理子, 井口治巳, 野間和夫 橋本恵次, 近藤康雄, 増田一孝

【目的】当院では192Ir高線量率腔内照射治療時(婦人科領域)には, 毎 回CT撮影を実施し, ターゲットおよびリスク臓器 (直腸, 膀胱)の線 量評価を行っている. 今回, 婦人科領域 (胵断端部一外陰部) 治療時 に扔いて,リスク臓器の線量低減 (主に直腸線量)を目的に, 臸アプ リケータ 2 種(1ツ穴および2ツ穴)にそれぞれスペーサを装着し， ターゲットおよびリスク臟器の線量評価を行った。

【方法】症例 1 -臸中央部〜外陰部 (1 ツ穴アプリケータ), 症例 2 胵断端部一外陰部(2ツ穴アプリケー夕)において，スペーサ装着無 しおよびスペーサを目的臟器側に装着した時の, ターゲットおよび リスク臟器線量の比較検討を行った。なお，それぞれの症例は，治 療回数 4 回の内 2 回をスペーサ装着とした。また, 線量評価はそれ ぞれの治療開始前に取得したCT画像を用いて行った。

【結果】症例 1 では, 直腸線量最大値 ( 2 回平均)で $26 \%$ の低減となり, 症例 2 では, 直腸線量最大值 ( 2 回平均) で $32 \%$ の低減となった。 な お, ターゲット線量においては, 両症例とも約 $5 \%$ 程度低隇する部 分が生じた.また, 両症例とも直腸線量のDose Volume Histogramに よる比較においても，その有意差が確認された。

【考察】192Ir高線量率腔内照射, 婦人科領域治療においては, 重要臓 器障害を減らすために, 目的重要臟器側にスペーサを装着すること は有効であり,また, リスク臓器の線量評価に, CT撮影は必須であ ると考える.ターゲット線量における線量低減部分については, 治 療開始前に治療効果に与える影響について放射線治療医との検討が 必要と考える。

\section{$317{ }^{60} \mathrm{Co}$ 密封小線源の線源近傍の深部線量}

福岡大学病院·放射線部 長松健一, 吉川治雄, 田中 稔

澤田登美子，上田嘉郁，稲富孝治

九州大学・医学部保健学科 上原周三

【目的】外照射に用いられる ${ }^{60} \mathrm{Co}$ の深部線量曲線は平行線束照射下に おいて $0.5 \mathrm{~cm}$ の位置にピークをもつ. しかし， ${ }^{60} \mathrm{Co}$ 密封小線源の場合 は平行線束ではないビームを放出する. 今回, ${ }^{60} \mathrm{Co}$ 密封小線源近傍 に扮ける深部線量曲線を検証した。

【使用機器】 ${ }^{60} \mathrm{Co} /{ }^{192} \mathrm{Ir}$ 線源選択型りモートアフターローディングシス テムmulti source(ドイツ STS社製)，線源60 Co (67.6GBq 2002.12.5)， 形状 直径0.6mm 長さ3.5mmの線状, UNIDOS chamber TYPE31006 $0.15 \mathrm{cc}$ (PTW社)，水ファントムMP3(PTW社)

【方法】1. 水中での実測における相対線量測定と同一条件下でのモン テカルロシミュレーション線量計算 ピンポイントチェンバーを使 用し, 線源中心を 0 として線源に最も近づく位置から $1 \mathrm{~cm}$ までを $1 \mathrm{~mm}$ 間隔で， $8 \mathrm{~cm}$ までを $5 \mathrm{~mm}$ 間隔で測定し線量減弱曲線を測定し た。また計算コードMCEP(九州大学上原)を用いて同一条件下で計 算を行った． 2. 入射角の違いによるモンテカルロシミュレーション 線量計算 線源から測定点に対して入射角度を一 90 度から 90 度まで 拡げて, モンテカルロシミュレーションによる線量計算を行った。 【結果】1、実測值とモンテカルロシミュレーションによる計算值の線 量曲線にほぼ差異はない．2. ビームの入射角度が拡がるにつれピー クが線源側に近づく.

【結論】 ${ }^{60} \mathrm{Co}$ 密封小線源での深部線量曲線は線源近傍でビルドアップ は認められない，したがって， ${ }^{60} \mathrm{Co}$ 密封小線源を利用する放射線治 療に扔いて線源の近傍においても線量不足にならないことを示して
いる.

318 簡易測定ファントムと反射型フィルムを利用したI-125 Seed 線源のQA/QC

徳島大学・医学部保健学科 笈田将皇，八木浩史

徳島大学病院・診療支援部佐々木幹治，富永正英，原康夫 徳島大学・医学部放射線科 西谷 弘

【目的】近年，I-125 Seedによる前立腺がん小線源治療が普及しつつあ る.今回，我々はファントムを作製し，反射型フィルムを利用した 線源強度の検出精度改善を試みたので報告する。

【方法】反射型フィルムは，GAFCHROMIC-Film RTQAを使用した。 同一検定日のI-125線源 (約 $11 \mathrm{MBq}$ ) 11個をアクリルファントム (自作) 内に配置し，フィルムに近接させて一定時間 [60分を基準，54分(10\%)，63分(+5\%)]照射した. その後, フィルム解析システム $(\mathrm{DD}-$ System)により青色デジタルフィルタを通して照射直後と24時間後に フィルムをスキャンした。フィルム解析から線源近傍に関心領域 (ROI) を設定し，平均ADC(Analog-Digital Conversion)值を得た。照 射時間，ROIの大きさ $(5 \sim 100$ pixel円 $)$ ，照射経過時間，ADC值につ いて統計解析を行い, 最適なデー夕取得パラメータを探索した.

【結果】平均 $\mathrm{ADC}$ 值はROIの大きさ, 線源強度, 照射時間に依存して 経時的に変化した． 24 時間後の值は照射直後に比べて $0.7 \sim 1.8 \%$ 増加 した. ROIを小さくするにつれて平均ADC值の上昇，変動幅の増大 がみられるが，線源と同等のROI (40～60pixel)を設定することで良 好な検出精度が得られた。基準照射群に対し，-10\%，+5\%の照射 群では有意に差を検出できた $(\mathrm{p}<0.05)$ ．また， $-10 \%$ 照射群では高 感度で強度の違いを検出できた。

【結論】反射型フィルムを利用した線量測定では, 経時的変化, ス キャナ，フィルム特性の影響を考虑しなければならないが，10\%を 超える線源強度の違いは有意に鑑別可能であった.ファントムの作 製により，簢便かつ安定した精度でI-125 SeedのQA/QCを行うこと が可能となった.

319 CRT-GOS (Conformal Radiation Therapy with Gravity Oriented Shield)法による線量分布の基礎的検討

黒部市民病院・中央放射線科 松嶋正則，下田政儀，米田 剛 米沢辰男

金沢大学大学院. 医学系研究科 田中利恵, 菊池雄三 岐皁医療技術短期大学・診療放射線技術学科 内山幸男

【目的】椎体など馬蹄状の病巣に対する照射法として, IMRTに代わ り，MLCを用いた打ち抜き原体照射法(CRT-GOS法)が用いられてい る.この方法は, 打ち抜き吸収体を使用せずに原体の線量分布が得 られる簡便な照射法である反面, 高線量域の増加や専用ソフトウ工 アの採用などの問題もある. 本研究では, 線量分布の改善を目的と してCRT-GOS法にPhysical Wedgeを併用し, 各照射術式と比較, そ の有用性を検討した.

【方法】模擬計画として, CRT-GOS法の360回転(Arc) と固定20門 ウェッジなし (open), あり $\left(\mathrm{W} 15^{\circ}, \mathrm{W} 30^{\circ}, \mathrm{W} 45^{\circ}, \mathrm{W} 60^{\circ}\right)$ の 6 プラン をRTPs (Varian社製 Eclipse)で計画した。リニアック(Varian社製 Clinac2100C)X線10MVを水等価ファントム (Gammex社製 Solid Water)に照射し，フィルム法による測定を行った．線量分布の解析 はフィルム線量解析システムRIT113(日本バイナリー)を用いた. 90 \%から $105 \%$ の等線量曲線の画像データからフリーソフトを用い面 積を測定し, 治療計画に対する一致率・過小率・過大率, PTVのカ バー率を評価した。

【結果】1)V95のDVHはArcとW60齐良好であり，特にW60では高線 量域の体積が減少した．2） $90 \%$ 等線量曲線では $92 \%$ 以上の一致率, $8 \%$ 以内の過小率, $5 \%$ 以内の過大率, $95 \%$ 以上のカバー率であっ た. 3) $105 \%$ 等線量曲線のカバー率はopenが大きく, W60゙最も小 